\title{
URGENCY CRITICAL LEGAL STUDIES PARADIGM FOR THE PROTECTION OF WOMEN VICTIMS OF DOMESTIC VIOLENCE IN THE DIVORCE CASE
}

\author{
Nita Triana \\ Fakultas Syariah Intitut Agama Islam Negeri Purwokerto \\ Jln A Yani .No.40 A. Purwokerto \\ E-mail: triananita@ymail.com
}

\begin{abstract}
Abstrak: Penelitian ini menggambarkan tentang, perlindungan korban KDRT dalam kasus perceraian. Korban KDRT banyak tersembunyi dalam kasus perceraian di Pengadilan Agama. Paradigma positivistis yang dianut oleh para Hakim kurang memberi perlindungan terhadap korban KDRT, Metode yang digunakan dalam penelitian ini adalah metode kualitatif, jenis penelitian hukum doktrinal dengan pendekatan yuridis normatif. Korban KDRT di Pengadilan Agama membutuhkan paradigma baru untuk memberikan perlindungan pada korban KDRT. Hakim Pengadilan Agama yang berparadigma positivistik melihat hukum sebatas undang-undang. Hakim dalam memeriksa peristiwa KDRT dalam perceraian hanya berpegang kepada undang-undang yang berkaitan dengan perkawinan yaitu Undang Undang Nomor 1 Tahun 1974 dan Kompilasi Hukum Islam. Paradigma Critical Legal Studies. membangun kesadaran kritis dalam penegakan hukum dengan memperbaiki sistem hukum dan melakukan sebuah reformasi pada institusi yang bertanggungjawab atas perlindungan korban KDRT , salah satunya adalah Pengadilan Agama, Dengan paradigma Critical Legal Studies Hakim dalam memeriksa korban KDRT dalam kasus perceraian berpegang pada pandangan yang lebih holistik, dengan mempertimbangkan juga Undang-Undang PKDRT bahkan mencakup budaya hukum keluarga, masyarakat dan psikologi dan kesehatan.
\end{abstract}

Kata Kunci: Paradigma, Critical Legal Studies, Korban, KDRT,

Abstract: This research describes the protection of women victims of domestic violence in divorce cases. Domestic violence victims are hidden in divorce cases in the Religious Courts. The positivistic paradigm adopted by the Judges gives less protection to victims of domestic violence. The method used in this study is a qualitative method, a type of doctrinal legal research with a socio-legal approach. Domestic violence victims in the Religious Courts need a new paradigm to provide protection for victims of domestic violence. Religious Court Judges who have a positivistic paradigm see the law as a book (act). The judge in examining the domestic violence in divorce only adheres to the law relating to marriage, namely Law No. 1 of 1974 and Compilation of Islamic Law. Paradigm of Critical Legal Studies. build critical awareness in law enforcement by improving the legal system and carrying out a reformation in the institutions responsible for the protection of victims of domestic violence, one of which is the Religious Courts. 
Also consider the PKDRT Law No. 23 of 2004 concerning the elimination of domestic violence even covering legal culture of family, community, health and psychological .

Keywords: Paradigm, Critical Legal Studies, Victims, Domestic Violence

\section{Introduction}

The latest report from the National Commission on Violence Against Women (Komnas Perempuan) shows that the most constant domain and pattern of violence against women from year to year is domestic violence against wives. Based on documentation of cases reported and handled by various state institutions and service institutions, which were then summarized into 2017 Annual Notes ${ }^{1}$ Women found that of 259,150 cases violence against women, 10,205 cases of which are domestic violence / personal relations.

This pattern and realm is consistently the highest in the past three years. Of the 10,205 cases of domestic violence, violence against wives ranked highest at 57 percent (5,784 cases), followed by court

\footnotetext{
1 Grafik dimuat dalam Catatan Tahunan CATAHU Komnas Perempuan (https://www.komnasperempuan.go.id, downloaded August 18, 2018)
}

violence in 21 percent, and violence against girls, at 18 percent. The rest is violence by ex-husbands and exgirlfriends, violence against domestic workers and other personal domain violence.

The high number of domestic violence cases against wives is linear with data in the Religious Courts, that more than half of divorce cases handled by the MA (Supreme Court) (Sharia Chamber) and Religious Courts throughout Indonesia are caused by domestic violence. Violence includes domestic neglect, physical violence, psychological violence, and sexual violence. Divorce rates are also dominated by divorce by the wife rather than divorce, which shows the wife's strong initiative to stop domestic violence.

Most of the violence that occurs in victims of domestic violence is psychological violence. The problem, as disclosed by LBH 
$\mathrm{APIK}^{2}$ is that proof of psychic violence is not easy. The only way to prove is a letter from a psychologist. Psychic violence is actually already quite bright in the reason for filing for divorce because of the lack of responsibility, economic neglect and constant fights, greatly opening up opportunities for psychiatric domestic violence.

As explained in Chapter 1. General Provisions Article 1 In this Law what is meant by: 1 . Domestic violence is every act against a person, especially women, which results in the emergence of physical, sexual, psychological, and / or neglect of household including threats to commit acts, coercion or deprivation of liberty against the law in a household organization.

Religious Courts, as an instrument for seeking justice, are expected to resolve family disputes that can prevent further disunity within the family. The implementation of religious justice is

2 Adhitya Himawan dan Lili Handayani 2017, Pengaduan Kasus di Jakarta ke LBH APIK https://www.suara.com/news/.../2017pengaduan-kasus-di-jakarta-kelbh-apik, downloaded August 182018 also different from the general court because the Religious Judges also have the duty to reconcile and find a way of settlement outside the court in the form of mediation as mandated in PERMA (Supreme Court Regulations) Number 1 of 2008 concerning Mediation, before deciding cases in the litigation process. Therefore a more empathetic and familial atmosphere is an important factor to consider in completing cases in the Religious Courts $^{3}$.

Understanding the psychosocial context of victims who are wrapped up in the cycle of violence, the cycle of isolation and confined to the power of the perpetrator, is very useful for judges in exercising their authority to resolve this family case. In general, women victims of domestic violence come to the Religious Courts to settle the domestic crisis is the final choice after taking various solutions. This is evident in almost all cases in the

${ }^{3}$ Abdul Manan and Fauzan, Pokok-Pokok Hukum Perdata Wewenang Peradilan Agama. : Rajawali Press, Jakarta. 2000.p.57 
Religious Courts which have always stated that there has been a peace effort (mediation) for both parties, but failed.

Judges have the authority to seek settlement of kinship before deciding to terminate the marriage. With such a situation, when interpreting matters in the Religious Courts it is important to be able to examine the issues in more depth and empathize with the victims. Judges in the Judge's Code of Conduct established by the Chair of the Indonesian Supreme Court are required to be fair. This means that the judge must place the parties equally before the law. However, judges are also required to be wise and prudent in the sense that judges must pay attention to gender fair norms that live in society, whether it is legal norms, religion, morality, and pay attention to the situation and conditions that exist and are able to take into account the consequences of their decisions.

A holistic view is needed by Judges in the Religious Courts, it requires a new paradigm of thinking in the field of law such as the Critical Legal Studies paradigm, a new paradigm of thinking about the operation of law. Critical Legal Studies was born to fight for justice for the oppressed, the law in this paradigm not only applies the principle of certainty but more broadly is the principle of justice. How to achieve this common goal is an effort and steps that have been tested for decades in the world.

Based on this background, it is very important to analyze the protection of women victims of domestic violence in divorce cases in the Religious Courts with the paradigm of Critical Legal Studies, which encourages judges to be more sensitive to domestic violence issues that are often hidden in divorce cases in the Religious Courts. This research is a doctrinal legal research with a socio-legal approach. The data obtained from the research library with the method used is qualitative 4

\footnotetext{
4 Strauss and J Corbin, Busir, Qualitative Research, Grounded Theory Procedure and Techniques, London: Sage Publication, 1990. p.34 See also J.L.K Valerine, Metode Penelitian Hukum: $\quad$ Kumpulan Bahan Bacaan untuk Program S2 dan S3 (Jakarta: Program Pascasarjana FHUI, 2014 . p.82
} 


\section{Domestic Violence in National}

\section{Law and Islamic Law}

Domestic violence according to the viewpoint of National Law, contained in Law No. 23 of 2004. Whereas the implementation of this Law is actually an implementation of a country that ratified the convention on the elimination of all forms of discrimination against women (Convention on the Elimination of All Forms of Discrimination / CEDAW) through Law No. 7 of 1984. Also based on the Declaration of Elimination Violence Against Women born by the United Nations on 20 December 1993 and ratified by the Indonesian government. Even in Indonesia, Law No. 23 of 2004 concerning apusan Elimination of Domestic Violence ${ }^{5}$ has been approved.

Domestic violence as stated in Law No.23 of 2004 concerning the Elimination of Domestic Violence has the meaning of every act against a person, especially women, which

5 Lianawati Ester ,. Konflik Dalam Rumah Tangga Keadilan \& Kepedulian Proses Hukum KDRT Prespektif Psikologis Feminis. Paradigma Indonesia, Yogyakarta 2009. p.92 results in the emergence of misery or suffering physically, sexually, psychologically, and / or neglected home ladder includes threats to commit acts, coercion or deprivation of liberty unlawfully within the household. The problem of domestic violence has received legal protection in Law Number 23 of 2004 which, among other things, confirms that:

- Whereas every citizen has the right to get a sense of security and freedom from all forms of violence in accordance with the philosophy of Pancasila and the Law of the Republic of Indonesia in 1945.

- Whereas all forms of violence, especially domestic violence constitute human rights violations, and crimes against human dignity and forms of discrimination that must be removed.

- Whereas victims of domestic violence, most of whom are women, it must get protection from the State and / or the community so that they are protected and free from violence 
or the threat of violence, torture, or treatment that undermines the degree and dignity of humanity.

- Whereas based on considerations as referred to in letter $a$, letter $b$, letter $\mathrm{c}$, and letter $\mathrm{d}$, it is necessary to establish a Law on the elimination of domestic violence.

- Acts of violence committed by husbands against wives are actually a heavy element in criminal acts, the legal basis is the Criminal Code (book of criminal law) article 356 which outlines the contents of the article which reads: "Whoever mistreats father, mother, a wife or child is subject to criminal penalties"

The law on domestic violence is a public law in which there is a threat of imprisonment or a fine for those who break it. As for who is included in the household, are: a). Husband, wife and child, including adopted children and stepchildren; b). People who have a family relationship with a husband, a wife who lives in the household, such as: in-laws, son-in- law and brother-in-law, and c). People who work help in the household and live in the household, such as domestic workers.

The form of domestic violence as mentioned above can be carried out by the husband against his family members in the form of: 1) physical violence, which results in pain, falling sick or seriously injured; 2) Psychic violence, which results in a sense of fear, loss of confidence, loss of ability to act, feeling of helplessness, etc. 3). Sexual violence, which is in the form of sexual coercion in an unnatural manner, both for the husband and for other people for commercial purposes, or for certain purposes; and 4). Abandonment of households that occur within the scope of the household, which according to the law is obligatory upon it. Besides that neglect also applies to everyone who causes economic dependence by limiting and / or prohibiting decent work inside or outside the home, so that the victim is under the control of the person.

For victims of domestic violence the law has regulated the 
rights that can be sued to the services according to medical needs; perpetrators, among others: a). c). Handling specifically related to Protection from the family, police, victim confidentiality; d). Assistance prosecutors, courts, lawyers, social by social workers and legal assistance; institutions, or other parties as well as and e). Spiritual guidance service. In the determination of protection addition, victims of domestic violence orders from the court ; b). Health are also entitled to get services for the services according to medical needs; recovery of victims from, health c). Handling specifically related to victim confidentiality; d). Assistance by social workers and legal assistance; and e). Spiritual guidance service. In addition, victims of domestic violence are also entitled to get services for the recovery of victims from, health workers, social workers, escort volunteers and / or spiritual counselors. (vide, article 10 of Law No.23 of 2004 concerning Elimination of Domestic Violence (PKDRT).

For victims of domestic violence the law has regulated the rights that can be sued to the perpetrators, among others: a). Protection from the family, police, prosecutors, courts, lawyers, social institutions, or other parties as well as the determination of protection orders from the court ; b). Health workers, social workers, escort volunteers and / or spiritual counselors. (vide, article 10 of Law No.23 of 2004 concerning Elimination of Domestic Violence (PKDRT).

Domestic violence does not only constitute the National Law Constellation. But in the perfection of religious understanding, it has always been regulated in the respective Scriptures - Religion. Based on the viewpoint of Islam. In the household context, the husband has an obligation to educate his wife and children to obey Allah. This is according to the word of Allah, which means: " believers take care of yourself and your family from hell fire ..." (Qs. At-Tahrim [66]: 6). In educating these wives and children, it could be forced to do with a "blow". , 
"Punch" in the context of education or ta'dib is allowed with certain clear boundaries and rules.

The rules include: the blow that is given is not a painful blow, let alone to kill; the blow is only given if there is no other way (or all the methods have been taken) to give punishment / understanding; not beating when it is very angry (because it is feared it would be dangerous); do not hit vital body parts such as the face, head and chest; not beating more than three shots (unless very forced and not exceeding ten punches); may not beat children under 10 years of age; if a mistake is first made, then the opportunity is given to repent and apologize for his actions, etc.

\section{Urgensi Critical Legal Studies}

Speaking of law, we will be faced with a science with the aim of an almost endless object. The object named the law became so widespread $^{6}$ because it came into contact with a large number of

6 William J Chambliss and Robert B. Seidman, Law, Power and Order, Philipine, Addison-Wesley Publishing Company, 1971. p. 112 aspects of human life, say: human beings themselves as individuals, society, state, politics, socioeconomics, history, psychology, philosophy and aspects other aspects of life. The broad object target is a feature of the Critical Legal Studies (CLS) movement that was born in America. As a thought that seeks to make a breakthrough towards the enactment of the law against discrimination derived from the law, Critical Legal Studies was born to fight for justice for oppressed people / society by using various aspects of human life and society.

This is different from the current legal studies in the world, in legal positivism, legal certainty will only be realized if the law is considered a closed and autonomous system of various moral, religious, philosophical, political, historical and similar problems. For the adherents of legal positivism, legal certainty will be achieved not only because the law is formed by an authorized institution by following the system of legislation in force, but also if the law can work together - in a scientific framework - 
with various positive sciences (natural sciences and social sciences the way it works is based on natural science methods) to legitimize the various behaviors that exist in society ${ }^{7}$

Legal positivism actually departs from the assumption of classical liberalism about society as a group of individuals who are autonomous and have the same rights, then to realize common interests, these individuals are free to enter into social contracts to form the state and law. Consequently, the state and law must be neutral, objective, and not in favor of any individual. The spirit of social science postivism and then the dtrasnformation in legal thinking by Bentham, Mill and Austin within the framework of utilizationism $^{8}$

$$
\text { Ultimately legal postivism }
$$
produces objectivism and formalism. In the construction of the paradigm of postivism, then the set of legal

\footnotetext{
${ }^{7}$ Donny Danardono, Critical Legal Studies: Posisi Teori dan Kritik, Kisi Hukum Vol 14, No 1. 2015. pp.2-3.

8 Bernard L Tanya dkk, Teori Hukum: Strategi Tertib Manusia Lintas Ruang dan Generasi Yogya:Genta Publishing, 2013 .p.205
}

provisions is believed to be a neutral, impartial and must be enforced (not Subjective) tool. This is in line with Unger stating that the sanitation of modern law that grew in the 19th century was actually intended to serve a social order patterned in a competitive free market through freedom guaranteed by the democratic system. Therefore modern legal construction in the implementation of the fact is in favor of market interests and there is no partiality. The influence of the paradigm of postivism then gives birth to legal formalism.

In practice, the positivism in the Court is, in handling the case the Judge identifies the relevant principles and rules, there is no partiality (for the weak) and applies the rules deductively, without the help of other approaches ${ }^{9}$ (Triana, 2011: 256-257) the beginning of legal criticism by thinkers Critical legal studies (CLS). Intellectual roots of Critical legal studies (CLS) vary, but are most often

${ }^{9}$ Nita Triana . Progresifitas Hakim dalam Dinamika Positivisasi Hukum Islam di Indonesia, Al manahij Jurnal Kajian Hukum Islam. STAIN Purwokerto, Vol.V No.2,Juli .2011.pp.256-257 
associated with post structuralist realism and historism.

Critical footing from critical legal studies is also often painstakingly criticized by the criticisms of the Frankfurt School thinkers who carry out critical critics which are preceded by critical thinking built by Karl Marx and then grouped as Neo Marxian. Critical theory built by Frankfurt school thinkers was then used as a theoretical basis for the development of critical egal studies (CLS). Adherents of Critical legal studies (CLS) believe that the logic and structure of law arise from the existence of Power Relationship in society, the existence of the law is considered to support the interests or classes in society to form the law. Therefore the ruling class of society who will use the law as a tool to maintain their position. So that Critical legal studies (CLS) sue against the norms and standards in the theory and practice of law that have been taught
There are 2 (two) themes that are dominant in criticism launched by this CLS ${ }^{10}$. namely:

1. Legal institutions have been polluted from within, contributing to the absence of overall social order, and the law works primarily as a tool of power. In this theme, very clear legal alignments, which benefit the rich and harm and deceive the poor, are cited as incontrovertible evidence.

2. Criticism of liberal legalism (liberal legalism) itself, is about the idea that the objectives of justice can be achieved through an objective, impartial and autonomous system of rules and procedures.

These two themes are interrelated. The principle of the rule of law in liberal legalism has been unable to overcome the fundamental problems of social justice and has also become a major supporter of power.

${ }^{10}$ Roberto M Unger M , Teori Hukum Kritis: Kajian Tentang Posisi Hukum Dalam Masyarakat Modern. Bandung, Nusa Media, 2008, p.58 See also .Roberto M Unger, Law in Modern Society. Harvard: Harvard University Press. 1977.pp.2-6 
Building Critical Awareness with Critical legal studies (CLS) in law enforcement means improving the legal system ${ }^{11}$ and carrying out a reformation in the institution that is most responsible for the quality of law enforcement in this country. In connection with this matter, the planting of critical awareness is necessary as an effort to improve the quality of prospective law enforcement, at least those who will become law enforcement later and those who currently have become law enforcers do not see the law as a law (such as horse goggles $)^{12}$.

The Critical Legal Studies movement influenced Progressive legal thinking, as Satjipto Rahardjo ${ }^{13}$ quoted Taverne as saying, "Give me good prosecutors and judges, even with bad regulations, I can make good decisions". Prioritizing (human)

11 Lawrence M.Friedman. The Legal System: A Social Science Perspective. New York, Russel Sage Foundation, 1975. p.131

12 Suteki, Kebijakan Tidak Menegakan Hukum (Non Enforcement Of Law) Demi Pemuliaan Keadilan Substantif, Pidato Pengukuhan dalam Penerimaan Jabatan Guru Besar dalam bidang Ilmu Hukum pada Fakultas Hukum - Universitas Diponegoro. Semarang.UNDIP.2010. pp.53-61

13 Satjipto Rahardjo, Hukum Progresif Sebuah Sintesa Hukum Indonesia, Yogyakarta.Genta Publishing. 2009.p.67 behavior rather than legislation as a starting point for the law enforcement paradigm, will lead us to understand the law as a humanitarian process and project.

Prioritizing behavioral (human) and humanitarian factors above the regulatory factors, means shifting the mindset, attitudes and behaviors from the legalistic-positivistic level to the level of humanity as a whole (holistic), namely humans as individuals (individuals) and social beings. In this context, every human being has individual responsibility and social responsibility to provide justice to anyone. Progressive legal orientation rests on the regulatory and behavioral aspects (rules and behavior ${ }^{14}$

Regulations will establish a positive legal system that is logical and rational. While the behavioral or human aspects will move the rules and systems that have been built. Because of the assumptions built here, that law can be seen from the

14 Satjipto Rahardjo, Sekitar Hakim yang Memutus, Semarang . Kumpulan Tulisan Program Doktor Ilmu Hukum .UNDIP, 2009.p.98 
social behavior of law enforcers and their communities. By placing the behavioral aspect above the regulatory aspect, it is this human and humanitarian factor that has elements such as compassion (new feeling), empathy, sincerety, edication, commitment, dare (courage) and determination (determination $)^{15}$

Critical Legal Studies in the Protection of Women Victims of Domestic Violence in the

\section{Religious Courts}

The history of legal theory has been initiated as a reaction to the phenomenon of injustice that occurs in society. One theory that highlights injustice in the implementation of law in society, questions legal neutrality. These legal theories emerged along with the development of the critical legal studies movement in the United States. The movement which later developed into a new paradigm in looking at the law. Critical Legal Studies is a paradigm that seeks to

15 Syamsudin. M. Rekonstruksi Pola Pikir Hakim Dalam Memutus Perkara Korupsi Berbasis Hukum Progresif, Jurnal Dinamika Hukum.Vol.11 No.1. Januari.2011 UNSOED Purwokerto. 2011.p.11-13 make a breakthrough towards the enactment of the law which has given rise to discrimination against the weak (one of them is women).

Women in various domestic violence cases often have to face a dilemma. Domestic violence victims must choose between reporting violence perpetrators who are none other than their own husband who has been providing a living for the family or not reporting, which means women must forgive the perpetrator or allow violence to occur ${ }^{16}$. Legal conditions that do not provide this option, make women prefer to be silent, and allow themselves to be ensnared in conditions that are considered to have the least risk, namely allowing violence to continue and their rights neglected, or divorced.

Domestic violence should indeed be part of the general court.

16 Sulistyowati Irianto ; Antonius Cahyadi; Runtuhnya Sekat Perdata dan Pidana Studi Peradilan Kasus Kekerasan Terhadap Perempuan, Penerbit yayasan Obor. Jakarta 2008. p. 165 
However, in the event of a divorce, in the end it becomes the authority of the Religious Court. While in reality, the domestic violence problem can be considered a new item for Religious Judges. The judges need to be armed with knowledge about domestic violence to be able to resolve the case so that it is in tune with the sense of justice desired by the community.

Mastery of Law No. 23 of 2004 concerning the Elimination of Domestic Violence (Domestic Violence Law) is not a sufficient provision in the Religious Courts. In addition to this, the ability of Religious Court Judges in mastering Islamic teachings regarding households, progressive religious texts has a strategic role in eradicating domestic violence. Although the AlQuran and Al-Hadith place women and men in equal positions, a genderbiased view of no doubt contributes to the views of the interpreter of the primary text in Islam, namely the ulamas, jurists, and judges.

One important breakthrough was made by Religious Court judges in the divorce case, the judge not only referred to the law directly related to the case, but also explored other relevant regulations. That is to include the Domestic Violence Law as its legal reasoning, in fact, judges explore progressive religious texts that favor women. Religious courts do not have the authority to directly prosecute domestic violence. However, religious justice has a strategic role to uncover the form and reason for violence by hearing the voices of female victims. Religious Courts can be a place to accommodate women's hopes and desires regarding the household ark without stigma of blaming themselves continuously which is actually a victim of a gender-biased family relationship ${ }^{17}$. Therefore, the Judges, apart from being obliged to master the progressive religion of Islam. it should also have empathy to understand the roots of marital conflict problems which often cannot

17 learn more in the journal, Katherine Brickell , Clouding the Judgment of Domestic Violence Law: Victim Blaming by Institutional Stakeholders in Cambodia, Journal Of InterpersonaViolence . Publish by Sage. May 2017. 32(9). p.1359 
be seen in the conditions that occur at that time

Judges in the Religious Courts are time to shift from the paradigm of legal positivism to critical legal studies. The positivism paradigm is indeed unable and unable to interpret unequal power relations in a case that occurs in society, it is time for Religious Court judges to pay attention to the critical legal studies paradigm, that victim-centered policy considerations provide guidance for organizing legal materials, for evaluate and make changes to the law, and the application of law, together with other policy considerations, all of which are recognized as sources of law. Politically, the basic values in question are underlying vision and priorities, and thus strategies to advance the interests of victims of domestic violence (most of whom are women).

Applying legal provisions in divorce cases in which there is domestic violence in the paradigm of Critical Legal Studies is to apply a legal perspective holistically, namely by examining the legal provisions while remembering the experiences and interests of victims of domestic violence (usually women). The purpose of examining legal provisions holistically is to understand them in total. Understanding the legal provisions that cause and cause women to experience injustice and discrimination requires a thorough study of the law and women's experience. This means that we must find and identify relationships in the prevailing legal system, in the prevailing social system, in various fields such as historical background, economics, religion, politics, culture, psychology, and biology and so on.

Mastery and holistic analytical skills Religion Court Judges are urgently needed to deepen sociopolitical and economic analysis in every divorce case so that its strategic role in eradicating domestic violence at the Religious Court level is maximized.

In the paradigm of critical legal studies, the Judge can see divorce claim cases on the grounds that domestic violence is more holistic, it can be with economic and social 
reviews, for that the Judge can ex officio determine in his ruling that the husband is still charged with mut'ah living which must be paid to his wife, and The judge can look for juridical references, namely Article 147 of the Compilation of Islamic Law.

In practice so far, generally the wife who filed for divorce for various reasons including the reason for the occurrence of domestic violence, only included petitum requesting the religious court to divorce the marriage between the wife and her husband. Starting from the petitium and based on valid evidences, the religious court granted the divorce claim with amar dropping the divorce of one bain sughra without the other amor. However, behind this, after the religious court judges participated in various trainings related to gender justice, there were several legal breakthroughs which included amber which sentenced husbands to commit domestic violence in the form of financial charges packaged in mut'ah terms, as compensation for the suffering suffered by wife.
Holistic analysis Religious Court judges have provided "sufficient" legal protection for victims of domestic violence. Because besides the court decided the marriage of Article 189 RBg. / 178 article HIR 11. The actual use of the term mut'ah is not appropriate, but using the legal term "compensation" is also far less irrelevant, because "compensation" is outside the scope of authority religious court. The term "compensation" in practice is a compensation for acts against the law that are the jurisdiction of the general court.

Presumably the legal ijtihad of the first level judges is in line with the Supreme Court, as seen in jurisprudence number $137 \mathrm{~K} / \mathrm{AG} /$ 2007 dated February 6, 2008. Legal considerations in the Supreme Court ruling reads that the wife who sues for divorce is not always punished by nusyuz so that the husband is the defendant was convicted of paying a living to his wife, because his wife underwent a term which involved the interests of her husband. Despite the different cases, the Supreme Court 
found a ratio decidendi which could be used as a basis for punishing a husband who committed domestic violence against his wife.

In another event for various divorce claim cases, after a holistic analysis was conducted, in terms of psychology, a case was found that actually there was a divorced woman who did not want to divorce. but instead stated that he wanted to return to her husband to defend his marriage, the divorce claim actually only wanted to make her husband aware of not doing domestic violence.

This data must also be read that a wife who filed a divorce to court did not all want a divorce. These data can also be a sociological basis as well as a node between the Religious Courts that examine divorce cases with the provisions of the husband's punishment for counseling. In other words, when the Religious Court examines and adjudicates the divorce case and discovers the fact that the wife actually only wants her husband's behavior to change, the Religious Court has juridical opportunities to determine the husband to follow counseling as intended in Article 50 of Law no. 23 of 2004 .

This juridical opportunity can be found in the reference to the principle of court proceedings in a simple, fast and low cost. By integrating counseling sentences for husbands who commit domestic violence with divorce, the principle can be fulfilled. In addition, the punishment of counseling for the husband of domestic violence perpetrators can realize the goal of punishment, among others, to educate the perpetrators to obey the law and government, in addition to improving criminal behavior. Moreover, it turns out that the perpetrator's wife of violence actually did not want to divorce (read: separate) from her husband despite having committed domestic violence.

However, because the religious court is passive ${ }^{18}$, the verdict that punishes the husband for counseling must be based on the lawsuit filed by

\footnotetext{
18 Yahya M Harahap , Kedudukan kewenangan dan acara Peradilan Agama, Jakarta: Pustaka karsuni, 1990), p.122
} 
the wife. In other words, a wife in a divorce suit who argued that there was a domestic violence, also filed a petitum so that the husband was sentenced to counseling, because if the court decided by amar to determine the husband followed the counseling, while in the petitum his wife did not submit the matter, the violating judge of the ultra petita principle.

Therefore, divorce claims on the grounds that domestic violence is declared proven, therefore the lawsuit is granted in accordance with the petitum. This means that the divorce lawsuit granted by amar is usually dropped the Talak bain sughra (husband). And if the wife also proposes petitum so that the husband follows the counseling, then with the same evidence, the judge has no reason to refuse to punish the husband for counseling.

Efforts made by the Religious Court Judge to provide protection to the victims of domestic violence by divorcing marriages and providing financial compensation or counseling for the husband of perpetrators of domestic violence are the efforts made by the Judge to achieve justice. The Judge's decision ideally based on the principle of independence and independence which is reflected in every decision of the Court, is substantially a decision that can be accounted for both vertically and horizontally. Vertically it can be accounted for to God Almighty, according to the principle that is a bond that is "For the sake of justice based on the Almighty God". This decree must be pronounced when deciding the case, because if you don't or forget to read it, the decision is null and void. These images describe a sense of kebatinan that before a judge taps a hammer, it means he has communicated intensely with his Lord .

Decisions must also be accounted for horizontally, namely the decisions produced must be morally accountable to humans, in accordance with the objectives of the law itself. Pancasila in the context of systematic systematization in the main points of the 1945 Constitution. These main points include the 
mystical atmosphere of the 1945 Constitution and the realization of legal ideals (Rechtidee) which master the basic laws of the state both written and unwritten laws, so affect the torso, namely the articles contained in the 1945 Constitution and all legal products that are under it.

In carrying out its duties and functions, every element of the law enforcement apparatus has been equipped with a set of rules and professional codes of ethics as guidelines that must be followed. For the judicial apparatus, they must understand well their duties and obligations as normatively regulated in Law Number 48 of 2009 concerning Judicial Power, among others:

a. The court judges according to the law by not discriminating against people (Article 4 paragraph 1)

b. The court assists justice seekers and tries to overcome all obstacles and obstacles to achieving a simple, fast, and lowcost trial (Article 4 paragraph 2) c. Constitutional judges and judges must dig, follow, and understand the legal values and sense of justice that lives in society (Article 5 paragraph 1)

d. The court is prohibited from refusing to examine, hear, and decide on a case that is filed on the pretext that the law does not exist or is unclear, but is obliged to examine and try it (Article 10 paragraph 1)

e. The Supreme Court can provide information, consideration and advice on legal issues to state institutions and government institutions (Article 22 paragraph 1)

In addition to the foregoing, given the legal provisions that are always left behind with the needs and development of society, then the judge has to do a comprehensive legal study called legal interpretation. Judge's conception in interpreting the law can be divided into 2 (two) theories namely heteronomous legal discovery theory and autonomous legal discovery theory. The heteronomous legal discovery theory 
places the judge as the mouthpiece of the law (la bouche de la loi) while the autonomous legal discovery theory place judges on one freedom to understand and link laws according to community development. The fundamental difference between the two theories lies in the extent to which the judge is bound to the provisions of the written law .

In almost the same language, Van Apeldoorn explained that the essence of the interpretation activity was an attempt to find the will of the legislator whose statement was unclear. The function of legal interpretation is basically 4 (four), as follows:

1. To understand the meaning of legal principles or rules,

2. Linking legal facts with legal rules,

3. Guarantee the application or law enforcement that can be carried out appropriately, correctly and fairly

4. Bringing together the rule of law with social changes so that the actual legal rules are able to meet the needs in accordance with changes in society.

The use of interpretation as the influence of community development basically opens up opportunities for judges to progress lawfully. The judge not only explores the values that live in the community but also follows the development of the appreciation of these values in the community. This is where the meeting point between legal discovery and progressive law provides convenience and possibilities for judges to produce new breakthroughs in deciding cases .

In this case the judge carries out his role as a judicial institution by doing legal interpretation of the existing rules to produce a rule of law as a basis for adjudicating. With the freedom to interpret, the judge can also find the law in every interpretation. From the word "legal discovery" implicitly shows the existence of a law that has been applied in the community, but it is not clearly known so that it takes effort to get it.

In the tradition of legalpositivism thinking, which is widely 
adopted by the democratic state today, the law is conceived as a product of legislation. The law is the legislation produced through the national legislation process. The law applies, solely because it has been stipulated in the form of laws and regulations, regardless of whether it contains values of justice or not. In this system, legal actors (judges and bureaucracy), as well as the doctrine in analytical jurisprudence, only serve as trumpets or mouthpieces of the law ${ }^{19}$ (Irianto and Shidarta: 2013: 24).

According to Satjipto Rahardjo , the law should be in charge of serving humans, not the other way around. Legal quality is determined by its ability to serve the community. This is a progressive law, which adheres to a pro-justice law and a pro-people law. This progressive law, offered to overcome the crisis in the current global era. The dedication of legal actors has a major place to make improvements. Legal actors must have empathy and concern for the suffering experienced by the people

19 Sulistyowati Irianto dan Sidharta, Metode Penelitian Hukum: $\quad$ Konstelasi dan Refleksi Ed, (Jakarta:Yayasan Pustaka Obor-JHMP FHUI, 2013),p.24 and nation. The interests of the people must be the main orientation and the ultimate goal of law enforcement. In the concept of progressive law, the law does not serve itself, but for purposes outside itself. This is different from the analytical jurisprudence tradition that tends to ward off the outside world; like humans, society and their welfare.

In the view of progressive law, legal actors must have sensitivity to crucial issues in terms of human relations, including human restraint in oppressive structures; both political, economic and socio-cultural. In this context, progressive law must appear as an emancipatory (liberating) institution. Progressive law that requires liberation from the tradition of obstruction, has a resemblance to Roscoe Pound's thinking about law as a means of social engineering. Social engineering business, is considered as an obligation to find the best ways to advance or direct the community.

The judge as a state justice official who has the authority to receive, examine, and decide on the case that is confronted with him. In 
essence, the task of the judge to judge contains two senses, namely to uphold justice and enforce the law. Therefore, the judge in carrying out his duties is given freedom and independence guaranteed by law. This is very important, with the aim of creating law enforcement that is just and guaranteeing human rights ${ }^{20}$ (Anonim, 2018).

According to Gerhard Robbers contextually there are 3 (three) essences contained in the judge's freedom in exercising judicial power, namely (Rahardjo: 2009: 80)

1. Judges are only subject to law and justice

2. No one including the government can influence or direct decisions that will be handed down by the judge, and

3. There should be no consequences for the judge's personality in carrying out his duties and judicial functions.

The freedom of the judge in examining and adjudicating a case is a

${ }^{20}$ Anonim. Pedoman Perilaku Hakim (Code of Conduct) Mahkamah Agung Republik Indonesia. 2018 crown for the judge and must be guarded and respected by all parties who can intervene in the judge in carrying out their duties. Judges in making decisions, must consider many things, both those relating to the case being examined, the level of actions and errors committed by the perpetrator, to the interests of the victim and his family and also consider the sense of justice of the community.

Judges have free discretion, their feelings about what is right and what is wrong are the real direction for achieving justice. With an independent judicial power, this will support the judge's performance in deciding the case that confronted him in deciding the case he faced. Judges in the trial must pay attention to the principles of the judiciary with the aim of making the decision objectively without being tainted by personal interests or other parties by upholding the principle. In addition, judges are also not justified in showing impartiality or sympathy for parties who are litigants, both in speech and behavior. 
The most important task of a judge is to impose a verdict on the case he received and examined. Judges' decisions will be felt so appreciated and have authority values, if the decision reflects the sense of legal justice of the community and is also a means for justice seekers to get truth and justice. So, in its decision the judge must consider all aspects of a juridical, sociological and philosophical nature, so that the justice to be achieved can be realized, and accounted for in the judge's decision that is just and oriented towards legal justice, social justice, and moral justice

\section{Conclusion}

Protection of women victims of domestic violence, many are hidden in divorce cases in the Religious Courts. Therefore the position of the Religious Court Judge is very strategic in providing protection for victims of domestic violence. Thinking Paradigm Judges are currently still in a paradigm that is positivistic, this results in protection for women victims of domestic violence is not optimal. Therefore, it needs a new paradigm. The paradigm of Critical Legal Study, as a paradigm of Building Critical Awareness with Critical legal studies (CLS) in law enforcement means improving the legal system and carrying out a reform of the institutions responsible for the protection of victims of domestic violence, one of which is the Religious Court. In connection with this, the planting of critical awareness is necessary as an effort to improve the thinking paradigm of law enforcers, in this case the Religious Court Judge does not see the law positivistically as a law related to marriage, namely Law No. 1 of 1974 and Compilation of Islamic Law, but more holistic, taking into account the PKDRT Law No. 23 of 2004 concerning the elimination of domestic violence even covering legal culture of family, community , health and psychological .

\section{References}

Anonim. Pedoman Perilaku Hakim (Code of Conduct) Mahkamah Agung Republik Indonesia. 2018 
Ester Lianawati, . Konflik Dalam

Rumah Tangga Keadilan \&

Kepedulian Proses Hukum

KDRT Prespektif Psikologis

Feminis. Paradigma

Indonesia, Yogyakarta

2009.

Fakih Mansour, Analisis Gender dan Transformasi Sosial, Pustaka Pelajar, Yogyakarta, 2003

Friedman.M.Lawrence. The Legal System: A Social Science Perspective. New York, Russel Sage Foundation, 1975.

Harahap M. Yahya, Kedudukan kewvenangan dan acara Peradilan Agama, Jakarta: Pustaka karsuni, 1990),

Irianto Sulistyowati; Antonius Cahyadi; Runtubnya Sekat Perdata dan Pidana Studi Peradilan Kasus Kekerasan Terbadap Perempuan, Penerbit yayasan Obor. Jakarta 2008.

J. Chambliss William and Robert B. Seidman, Law, Power and Order, Philipine, AddisonWesley Publishing Company, 1971.

Manan A dan Fauzan, Pokok-Pokok Hukum Perdata Wewenang
Peradilan Agama. : Rajawali Pers, Jakarta. 2000.

RahardjoSatjipto Hukum Progresif -
Sebuah Sintesa Hukum
Indonesia,
Yogyakarta.Genta
Publishing. 2009

Sekitar Hakim yang Memutus, Semarang . Kumpulan Tulisan Program Doktor Ilmu Hukum .UNDIP, 2009

Tamanaha Z. Brian. On the Rule of Law, New York: Cambridge University Press.2004 A Concise Guide to The Rule of Law, Legal Studies Research Paper, 070082, New York, St John University School of Law 2007

Unger M Roberto Law in Modern Society. Harvard: Harvard University Press. 1977

Unger M Roberto, Teori Hukum Kritis: Kajian Tentang Posisi Hukum Dalam Masyarakat Modern. Bandung, Nusa Media, 2008,

Strauss and J Corbin, Busir, Qualitative Research, Grounded Theory Procedure and Techniques, 
London: Sage Publication, 1990.

Tanya L Bernard, dkk, Teori Hukum:

Strategi Tertib Manusia Lintas

Ruang dan Generasi,

Yogya:Genta Publishing,

2013

Valerine, J.L.K., Metode

Penelitian Hukum:

Kumpulan Bahan

Bacaan untuk Program

S2 dan S3 Jakarta:

Program Pascasarjana

FHUI, 2014

\section{JOURNAL}

Brickell Khaterine, Clouding the Judgment of Domestic Violence Law: Victim Blaming by Institutional Stakeholders in Cambodia, Journal Of InterpersonaViolence . Publish by Sage. May 2017. 32(9)

Danardono.Donny, Critical Legal Studies: Posisi Teori dan Kritik, Kisi Hukum Vol 14, $\underline{\text { No } 12015}$

Irianto Sulistyowati dan Sidharta, Metode Penelitian Hukum: Konstelasi dan Refleksi,

Ed, Jakarta:Yayasan Pustaka Obor-JHMP FHUI, 2013)
Syamsudin. M. Rekonstruksi Pola Pikir

Hakim Dalam Memutus

Perkara Korupsi Berbasis

Hukum Progresif, Jurnal

Dinamika Hukum.Vol.11

No.1. Januari.2011 .

UNSOED Purwokerto. 2011

Suteki, Kebijakan Tidak Menegakan Hukum (Non Enforcement Of Law) Demi Pemuliaan Keadilan Substantif, Pidato Pengukuhan dalam Penerimaan Jabatan Guru Besar dalam bidang Ilmu Hukum pada Fakultas Hukum - Universitas Diponegoro.

Semarang.UNDIP.2010

Triana Nita. Progresifitas Hakim dalam Dinamika Positivisasi Hukum Islam di Indonesia, Al manahij Jurnal Kajian Hukum Islam. STAIN Purwokerto, Vol.V No.2,Juli .2011

\section{INTERNET}

Grafik dimuat dalam Catatan Tahunan (CATAHU) 2017 (https://www.komnaspere mpuan.go.id, di unduh 18 agustus 2018 ) 


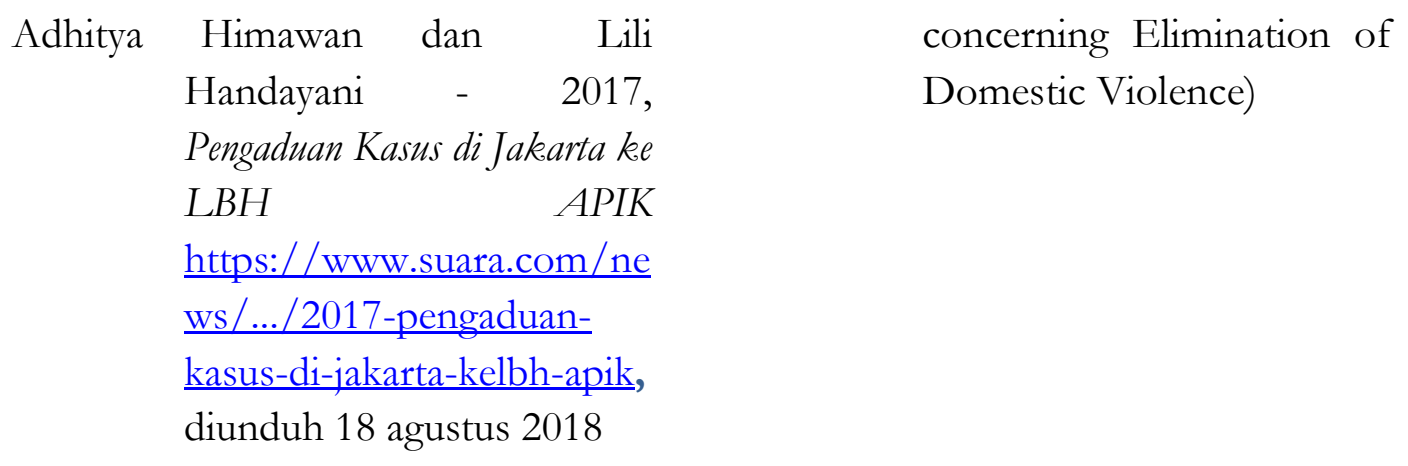

\section{LAW}

Konstitusi Undang Undang Dasar 1945 (Constitution of 1945)

Undang-Undang No.1 Tahun 1974 tentang Perkawinan (Law. No. 1 of 1974 concerning marriage)

Kompilasi Hukum Islam (Presidential Instruction No.1 of 1991 concerning Compilation of Islamic Law)

Undang-Undang No.7 Tahun 1984 tentang Pengesahan Konvensi Mengenai Penghapusan Segala Bentuk Diskriminasi Terhadap Wanita. (Law No.7 of 1984 concerning Ratification of the Convention concerning the Elimination of All Forms of Discrimination Against Women)

Undang-Undang No. 23 Tahun 2004 tentang Penghapusan Kekerasan Dalam Rumah Tangga (UU no. 23 of 2004 